\title{
ANÁlise OBJETIVA E APREENSÃO SUBJETIVA NA METAFÍSICA BERGSONIANA. A INTUIÇÁO DA VIDA E O CRIVO DOS FATOS
}

\author{
Débora Morato Pinto ${ }^{1}$
}

\begin{abstract}
Resumo: Este artigo intenciona mostrar como o método filosófico desenvolvido e aplicado por Bergson, a intuição, articula distintos níveis de nossa experiência. Para isso, buscaremos extrair algumas liçôes de um momento especial da aplicação desse método, no qual o mergulho na interioridade psicológica se relaciona com a visão objetiva da exterioridade. Trata-se aqui de retomar o bloco central da obra $A$ Evolução Criadora, núcleo metafísico da filosofia bergsoniana, no qual encontramos a reinterpretação dos dados da biologia que deriva na cosmologia. Mais precisamente, se a cosmologia elaborada nesse livro pode ser apontada como a performance mais paradigmática da intuição, nossa atençáo se dirigirá a um passo metodológico anterior: a leitura dos dados da biologia evolutiva que dá contornos e subsídios à tese de que a consciência é coextensiva à vida.
\end{abstract}

Palavras-Chave: Duração. Vida. Biologia. Cosmologia. Intuição. Experiência.

\section{INTRODUÇÁO - COMO RENOVAR A METAFÍSICA?}

Uma metafísica nova. É com notável frequência que se levantam as mais pesadas críticas ao pensamento de Bergson, devido à eleição desse objetivo. Como propor o retorno à metafísica, depois da avassaladora crítica de Kant? A resposta a essa questão atravessa praticamente todas as obras do filósofo, mas um pequeno mapa com os principais argumentos pode ser encontrado na conferência "Introdução à Metafísica", de 1903; modificado e republicado anos mais tarde na coletânea $O$ Pensamento e o Movente (de 1938), o texto delineia a renovação da metafísica a partir do estabelecimento de seu vínculo intrínseco com a experiência. Ele recupera, sintetizando longas reflexões levadas a cabo em quatro grandes livros, a chave da proposta de superar os dilemas que o kantismo denunciou com maestria - assim, a discussão com Kant é ali franca e direta. Se fôssemos escolher uma declaração paradigmática, poderíamos explorar em vários níveis a seguinte afirmação: "As doutrinas que têm um fundo de intuição escapam à crítica kantiana na exata medida em que

\footnotetext{
${ }^{1}$ Professora Associada do Departamento de Filosofia da Universidade Federal de São Carlos. Orientadora credenciada no Programa de Pós-Graduação em Filosofia, na mesma instituição. Pesquisadora do CNPq desde 2006. E-mail: deboramorato@uol.com.br
}

http://dx.doi.org/10.1590/S0101-31732017000200002 
elas são intuitivas; e tais doutrinas são o todo da metafísica." (BERGSON, 2009, p. 225). Sem que compreendamos rigorosamente o sentido do termo "intuitivas" nessa frase, ela não passa de uma banalidade. Tal compreensão exige, entretanto, que o intérprete de Bergson faça convergir os vários - e aparentemente muito distantes entre si-empregos do termo intuição. Somente através do enfrentamento do problema da intuição, o que exige mobilizar com atenção, por sua vez, os usos da noção de experiência, variados e submetidos a importantes rearticulaçóes com o avanço das obras, é possível bem determinar como uma metafísica concreta - passível de se afirmar para além da crítica kantiana da razão e afinada com o nosso tempo - encontra suas condiçóes efetivas de realização.

No caso da passagem acima citada, intuitivas refere-se a um sentido preciso de intuiçáo: o ato que póe em movimento uma doutrina, uma filosofia, e que pertence unicamente ao filósofo que a inicia. Uma vez que a teorização é da ordem da produção discursiva de nosso entendimento e, nessa medida, opera essencialmente por análise, a indicação aqui consiste em algo que precede e condiciona o desenvolvimento analítico, mas que lhe é diferente em natureza. Bergson o define primeiramente como um impulso - termo que concerne, cabe sublinhar, tomando por vezes o lugar da noção capital de elá, ao movimento da vida que atravessa a materialidade, com ela criando organismos. Ao concretizar esse impulso em obra, isto é, em análises comunicadas ao menos a si mesmo, o filósofo já está no terreno da comunicação ao outro, no campo do que Bergson aponta como pedagógico (função imanente ao desenvolvimento da linguagem). O filósofo, ao dar corpo aos processos de conhecimento desencadeados por tal impulso, torna-se "mestre de si mesmo" e, por isso mesmo, discípulo, o que implica dissimular inevitavelmente esse ato originário: "[...] o ato simples, que colocou a análise em movimento e que se dissimula atrás dela, emana de uma faculdade inteiramente outra que a de analisar. Ele será, por definição, a intuição." (BERGSON, 2009, p. 225). Um impulso coloca em movimento um conjunto de análises, assim como a inspiração do poeta se materializa em versos e a vida se dissocia em organismos, os seres vivos que existem povoando a natureza. A metafísica renovada se definirá, portanto, como um movimento pelo qual um "estado subjetivo", ou sentimento especial, se concretiza em ideias, argumentos e teses, marcadas por uma particularidade cuja aderência à experiência resta esclarecer, nela incluída o que ciência e filosofia ordinariamente denominam "fatos".

Conciliar as variadas "definiçóes" da intuição em sua articulação 
com a análise é, então, o meio inelutável de aceder ao esforço preciso de uma nova metafísica, na exata medida em que ela exige superar os limites do conhecimento intelectual. Sem esse esforço, a razão está com Kant. Com ele, o próprio kantismo se explica e se supera. Em particular, duas direções contidas no termo intuiçâo sobressaem, por seu aparente antagonismo, quando buscamos essa conciliação: primeiramente, a noção psicológica de um sentimento vago, fugaz, profundo, em que a implicação recíproca, a multiplicidade contínua e os diversos graus de tensão articulados se anunciam - uma imersão num fundo difuso e movente, da qual será dito posteriormente que não só impulsiona, mas dirige análises, observaçôes, críticas e reflexóes e, num outro "polo", mais próximo do que ordinariamente se define como metódico, etapas que conformam propriamente uma investigaçáo teórica e que pressupóem processos de diferenciação e temporalização dos objetos mistos que são tratados pela ciência e pela filosofia como homogêneos e espaciais processos, portanto, analíticos. Etapas, aliás, que foram magistralmente expostas por Deleuze como atestado do rigor filosófico de Bergson: "A intuição não é um sentimento nem uma inspiração, uma simpatia confusa, mas um método elaborado, e mesmo um dos mais elaborados métodos da filosofia." (DELEUZE, 1999, p. 7). ${ }^{2}$ Assim, se a intuição pode ser justamente considerada como método rigoroso e resolvida em regras, a leitura deleuziana deixa de lado a primeira direção acima citada. De um jeito ou de outro, os comentários focados na questão do método em Bergson pararam por aí, sem que a dimensão propriamente "subjetiva" da intuição recebesse a atenção que lhe era devida.

Tratar das prerrogativas psicológicas, subjetivas ou afetivas de um método de conhecimento que se quer dirigido ao real, em termos de um absoluto, consiste num desafio que foge ao espírito do nosso tempo. Ocorre que outras etapas do método praticado por Bergson, precisamente aquelas que mais atraíram o interesse do debate filosófico, se transfiguram em procedimentos exteriores (e incomunicáveis) a tais prerrogativas, se elas não são tomadas seriamente em consideração. Dessa forma, os minuciosos processos de crítica das ilusôes da tradição filosófica, as desconstruções de conceitos afastados da experiência, as diferenciaçóes em natureza dos mistos mal analisados, a recolocação dos problemas em termos de tempo e, o que

\footnotetext{
${ }^{2}$ Mesmo aparentemente se contrapondo à noção de sentimento ou simpatia difusa, Deleuze reconhece um lugar para o intuitivo no sentido ordinário, algo da ordem da vivência; apenas reafirma que a intuição, no sentido rigoroso, é o que dá propriamente o meio de conhecer vivências e realidades. Sobre isso, ver todo o primeiro capítulo do Bergsonismo (DELEUZE, 1999, p. 7-26).
} 
nos interessa aqui, as discussóes instituídas diretamente com as ciências que reelaboram o material advindo da pesquisa em campos inovadores ao final do século XIX - todos esses passos avançados por Bergson, em suas obras, não podem ser compreendidos sem o retorno incessante à emoção própria do mergulho na interioridade que impulsiona efetivamente o esforço metafísico. Assim, enfrentar o desafio de reconectar as objetivaçóes da intuição da duração com o momento originário a partir do qual elas se desdobram tem efeitos inestimáveis para alcançarmos uma das intençóes filosóficas cruciais ao bergsonismo: o esclarecimento (e, consequentemente, a superação) da relação entre o arcabouço metafísico implicitamente assumido pelo saber (filosófico e científico, e isso especialmente no caso de uma revolução que invadiu ambos os terrenos, a biologia evolutiva do século XIX) e as descobertas, avanços e desenvolvimentos da ciência que apontam o descompasso entre esse solo não criticado e os fatos circunscritos pelos cientistas. Superar esse descompasso consiste justamente em retomar a metafísica em novas bases, e exige uma nova aliança ou convergência entre ciência e metafísica, a qual é plenamente assumida por Bergson como uma espécie de finalidade da intuição ou, ao menos, de seu próprio projeto filosófico:

A ciência e a metafísica convergem, portanto, na intuição. Uma filosofia verdadeiramente intuitiva realizaria a uniáo táo desejada entre a metafísica e a ciência. Ao mesmo tempo em que constituiria a metafísica como ciência positiva - progressiva e indefinidamente perfectível - levaria as ciências positivas propriamente ditas a tomar consciência de seu verdadeiro alcance, com frequência muito superior àquele que imaginam ter. (BERGSON, 2009, p. 137, grifo nosso).

Desse modo, um elemento essencial da resposta à questão que escolhemos para introduzir nosso texto - "como renovar a metafísica?" - atinge um alvo certeiro: com a ciência, de mãos dadas com ela. Surpreendentemente para um projeto filosófico que aponta limites para o conhecimento racional e apela a uma faculdade fora do espectro da psicologia e da teoria do conhecimento tradicionalmente desenvolvidas, a afirmação exibe, entretanto, uma marca expressiva da filosofia bergsoniana. Focalizaremos aqui a relação entre ciência e metafísica, num contexto preciso, o da teoria da vida e, mesmo sem adentrar no terreno da discussão com Kant, buscaremos delinear o que Bergson entende por teorias intuitivas. Mais explicitamente, acompanharemos uma das vertentes pelas quais a intuição se conforma em método, e isto se efetiva exatamente através da sua relaçáo intrínseca com a nossa experiência, 
contanto que nela estejam compreendidos (e implicados um no outro) seus níveis profundo/subjetivo e superficial/objetivo. O sentimento interior emoção profunda, como nomeia por vezes o filósofo - impulsiona um conjunto de procedimentos em que o papel do diálogo com a ciência é preponderante - a ciência é a ampliação, a sistematização e a exploração detalhada e rigorosa da experiência consciente elaborada pela inteligência, aquela mesma que Bergson primeiramente mostrou ser construida pelos expedientes do eu superficial. A distinção entre eu profundo e eu superficial constitui uma das mais importantes teses do Ensaio sobre os dados imediatos da consciência, e é condição, justamente por proporcionar a abstração dos efeitos de superfície na tentativa de encontro da interioridade psicológica depurada de elementos que lhe são exteriores, da apreensão da passagem do tempo enquanto tal - ou seja, da intuição da duração interior para além da sua deformação em tempo homogêneo. O trajeto da primeira obra pode ser resumido como a tentativa de afastar o eu "[...] que toca o mundo exterior por sua superfície" (BERGSON, 1993, p.93), e que invade inexoravelmente a relação com nossa interioridade, conduzindo-nos a pensá-la ao modo dos objetos físicos ou das causas materiais que afetam nossos sentidos:

[...] nossas sensaçóes sucessivas, mesmo fundindo-se umas nas outras, retêm alguma coisa da exterioridade recíproca que caracteriza objetivamente as suas causas; e é por isso que nossa vida psicológica superficial se desenrola num meio homogêneo sem que esse modo de representação nos custe um grande esforço. (BERGSON, 1993, p. 93).

A relação entre superficial e profundo, depois delimitada como o movimento próprio à intuição, se estabeleceu desde os primeiros passos do bergsonismo como problema a ser enfrentado e campo a ser conquistado.

Trata-se aqui, então, de extrair algumas liçôes de um momento da intuição em que o mergulho na interioridade psicológica pode ser articulado com a visada objetiva da exterioridade, sendo que a melhor explicitação desse modo de articulação reside no bloco central da terceira obra, núcleo metafísico da filosofia inteira de Bergson, no qual encontramos a reinterpretaçáo dos dados da biologia que deriva na cosmologia. Mais precisamente, se a cosmologia desenvolvida no coraçáo do livro pode ser apontada como a performance mais paradigmática da intuição (na medida em que o movimento entre o sentimento interior e a elaborada teorização sobre a natureza, ali percorrido, explicita o esforço metafísico), nossa atenção se dirigirá a um passo metodológico 
anterior, a um só tempo condição do que se segue: a reinterpretação dos dados da biologia evolutiva que dá contornos e subsídios à tese de que a consciência é co-extensiva à vida. Cabe acrescentar ainda que a compreensão desse centro nevrálgico do livro (o que implica a sua dependência em relação aos avanços metodológicos que ali são conhecidos) se tornou mais palpável para nós a partir de duas leituras contemporâneas de peso, as quais se propuseram exatamente investigar a intuição bergsoniana de maneira original, renovando o problema que permanecia quase intacto desde Bergsonismo (escrito em 1964). Seguemse, aqui, como preâmbulo à abordagem da teoria da vida, algumas observaçôes sobre tais leituras.

\section{EMOÇÃO, PROFUNDIDADE E SIMPATIA: LEITURAS RENOVADORAS SOBRE A INTUIÇÃO BERGSONIANA}

Reconhecendo o papel do Bergsonismo de Deleuze e o vácuo que se interpôs, no que diz respeito à intuição, entre essa obra e a retomada dos estudos bergsonianos pelas mãos de Frédéric Worms ${ }^{4}$, Camille Riquier define seu trabalho precisamente pela superação da tentativa de reduzir o método intuitivo a seus três atos cognitivos maiores, isolando-o "em torno de algumas regras". Ao buscar oferecer uma interpretação da integralidade do projeto bergsoniano, o autor vê na compenetração entre método e doutrina a vertente que escapou a outros estudos, e que impediu, para muitos leitores, cuja importância ele não subestima, que pudessem dar conta da originalidade desse método "[...] que deu à filosofia bergsoniana a unidade e a coerência de uma obra." (RIQUIER, 2009, p. 20). Para tanto, o autor parece simplesmente ter seguido de maneira fiel a lição de que uma metafísica nova é, antes de tudo, um novo modo de conhecer as realidades - de promover o conhecimento absoluto

\footnotetext{
${ }^{3}$ Foi preciso esperar a retomada em grande estilo que os anos 90 significaram para os estudos bergsonianos, para que em meio a vários outros (igualmente férteis) se destacassem aqueles que enfrentaram o desafio da relação entre intuição e metafísica, na chave própria de um espiritualismo renovado e pronto para ocupar o terreno do conhecimento, no século XX, tão antimetafísico quanto materialista. Mobilizamos aqui duas obras de fôlego que trazem nova luz para o problema da intuiçâo. Ver referências ao final do artigo.

${ }^{4}$ É certo que o estudo de Worms, Bergson ou les deux sens de la vie, apresentando uma hipótese original para dar conta do movimento da obra como um todo, avança muito sobre a intuiçấo, sobretudo ao indicar em seu conteúdo um alcance crítico. Mesmo que o método não seja o tema central desse estudo, ele abre caminho para leituras posteriores. Ressaltamos apenas a ênfase no que essa dimensão crítica da intuição aponta, segundo essa leitura: "[...] a confusão entre o espaço e o tempo nos mascara a realidade de nossa vida interior em nome das necessidades de nossa vida prática.” (WORMS, 2004, p. 10). A leitura de Worms buscará, assim, a unidade dos dois sentidos da vida distinguidos intuitivamente.
} 
do real, em sua multiplicidade de níveis. A metafísica é uma atitude face ao absoluto que se repete e se retoma incessantemente, levada a cabo por uma série de atos, que se instala no movente e dele passa a seguir direçôes variadas, a fim de atingir distintos graus da duração mesma. Em suma, a metafísica não é uma doutrina enquanto conjunto de teses e argumentos que derivariam da apreensão racional e total de um absoluto eterno e idêntico a si, mas sim um movimento, originado no ato de instalar-se na duração, que se dirige para baixo e para o alto, isto é, seja para a diluiçâo da tensão em mais diversos graus (cujo limite ideal seria a repetição pura), seja para a intensificação em que a duração se estreita e se aproxima de uma eternidade de vida: "[...] entre esses dois limites extremos, a intuição se move, e esse movimento é a própria metafísica." (BERGSON, 2009, p. 211). Assim, o ponto crucial se torna acompanhar Bergson no processo de elaboração metafísica que não deriva o real de um conceito, ao menos no sentido em que o fez a tradição, precisamente porque não "[...] se eleva acima da experiência e não pode aprisionar o absoluto num princípio" (RIQUIER, 2009, p. 9), e isso significa tratar o centro e ponto de partida da intuição, a duração de si, e seus desdobramentos como memória e elã vital, não mais como fundamentos, mas como implicados num fundo que não se conforma em solo, como tensóes ou variaçôes intensivas da "vida das coisas", na qual a intuição pode instalar-se e cujo movimento pode adotar e, assim, "atingir um absoluto" (BERGSON, 2009, p. 40). Nesse contexto, se o eu duro pode ser tomado como campo originário para a nova metafísica, é na medida em que ele permanece como fonte à qual se retorna recorrentemente, sem por isso se transformar em princípio definido e determinado, do qual se deduzem por sua vez as determinaçôes do real. A intuição da duração é, entâo, a descoberta de um novo sujeito, cuja profundidade, heterogeneidade e unidade múltipla poderão ser retomadas pelo mergulho ou imersão em si, isto é, num todo não fechado, totalidade dinâmica e aberta que responde pelos seus "efeitos" de superfície.

Nessa chave interpretativa, a metafísica de Bergson é, em primeiro lugar, a negação do fundamento sólido constantemente procurado pelos grandes projetos da tradição. $\mathrm{O}$ reverso dessa recusa consiste precisamente na aceitação do absoluto como fluidez ou dinamicidade, isto é, da temporalidade como estofo do real. É a atitude teórica, por vezes enfatizada por Bergson como esforço violento e antinatural, configurada pela tentativa de conhecer sem fundar, que define a inseparabilidade entre metafísica e método à qual se dedica Riquier. A fluidez é, para ele, a imagem mediadora da filosofia bergsoniana, uma matriz de imagens que convergem para a verticalidade do "[...] oceano 
vasto e profundo, sem margens nem balizas por nós fixadas." (RIQUIER, 2009, p. 54). A profundidade que remodela inclusive a relação ente sujeito e objeto pressupóe esse fundo movente, "espessura da duração" que comporta graus de tensão e extensão, no qual a filosofia tem que imergir e do qual pode retirar algo com que perscrutar o real. Encontramos, por conseguinte, o novo meio em que a filosofia deverá se mover, e que se contrapóe frontalmente à solidez do fundamento que a metafísica moderna, em especial a cartesiana, buscou descobrir - solidez da rocha - para, em seguida, nela fundar todo o conhecimento. ${ }^{5}$ A inversão proposta por Bergson, a qual atravessa as obras em minuciosas análises críticas dirigidas às ilusôes intelectuais, convoca a filosofia a sustentar-se num meio dinâmico, fluido, fugaz; em suma: "Bergson escolheu abandonar a rocha e arriscar dar conta do movente." (RIQUIER, 2009, p. 26). ${ }^{6}$

Ao seguir tais indicaçóes, somos conduzidos a lidar com o todo movente ao qual Bergson se referirá, no mais das vezes, através dos termos escoamento, jorro, mudança, transição, passagem, criação ininterrupta, vida contínua, entre outros. A multiplicidade e a continuidade da duração condicionam as diversas qualidades pelas quais o filósofo a descreve, condensadas numa expressão recorrentemente utilizada na obra: continuité d'écoulement. $\mathrm{O}$ contato ou visão do espírito pelo espírito, depurado da influência de conceitos a priori forjados na relação prática com o mundo, consiste na apreensáo subjetiva do tempo, à qual Bergson retornará em todos os momentos-chave de sua reflexão filosófica. A complexidade que envolve essa dimensão subjetiva decorre do fato de que sua apreensão conjuga um ato teórico contemplativo a dimensóes do espírito (em última análise, do real) que identificam essa visão “[...] ao movimento, ao

\footnotetext{
${ }^{5}$ Para o cartesianismo, com efeito, o terreno da metafísica é necessariamente sólido, e não à toa a metáfora escolhida para ilustrar a metafísica encontra-se da imagem da árvore: "[...] sua filosofia sustenta-se entáo pelo ego cogitans, isto é, pela subjetividade descoberta que se desdobra como seu solo." (RIQUIER, 2009, p. 25). Esse fundo é sólido, ele rejeita o movente como da ordem da areia, em nome de rocha.

${ }^{6}$ Vale a pena mencionar a continuidade dessas consideraçóes, por sua maneira feliz de situar Bergson entre dois pilares de projetos antagônicos. Afirma Riquier que o mérito da filosofia de Bergson, e a maturidade do seu método encontrada em $A$ Evolução Criadora deve evidenciá-lo, foi recusar a alternativa entre "o Grund e o Abgrund (o abismo de Heidegger)." Ao fazê-lo, delineando a unidade do real a despeito de seus atributos essenciais definidos como movimento, mudança e multiplicidade, Bergson foi capaz de deslocar a metafísica para um terreno móvel, cuja profundidade exclui toda referência fixa, e isso significa "[...] modificar consideravelmente a empresa inicial da metafísica, que foi desde o início a intenção de fundar.” (RIQUIER, 2009, p. 26). A teoria da vida vem então demonstrar como é possível "[...] abandonar a terra firme sobre a qual ele se enraizava para mergulhar na água imagem privilegiada por Bergson para sugerir o movente que é preciso pensar.”
} 
esforço e à criação." (FRANÇOIS, 2008, p. 40). ${ }^{7}$ A imersão na profundidade não pode ser descrita como mera experiência psicológica, mas não pode também ser apartada da emoção criadora, que é seu sentido essencial. Esse é o ponto: retomar a intuição em seu conjunto de atos significa buscar a interioridade do eu, atingida numa emoção (cujo caráter especial Bergson explora apenas na última obra, Duas Fontes), como condição mesma dos estados psicológicos que se objetivam em nossa experiência na vida. A ideia de origem e de gênese (da percepção do mundo, da inteligência que nos define como espécie, de nossa própria humanidade) está centrada nesse quase desconhecido plano da experiência, no qual a fluidez essencial da duração pode ser tocada em sua fugacidade inexorável. Todos os outros passos da metafísica estão condicionados por essa dimensão originária, e a intuição da duração envolve encontrá-la, bem como acompanhar sua unidade com as pontas da vida mental em nós para, posteriormente, retomar essa unidade entre o movente e as coisas na vida, na matéria e mesmo na sociedade. Para superar os quadros intelectuais e desvendar a própria origem da inteligência - mobilizando potências complementares de conhecimento, nas quais reside o passaporte para a superação da crítica kantiana - é indispensável, portanto, aceitar a imersão nesse oceano profundo e obscuro. Partindo do movente, a crítica bergsoniana não apenas ultrapassa os limites impostos pela "razão pura", como dá conta de sua gênese, de seu campo originário e do movimento pelo qual ela se formou, sob o preço da condensação ou da solidificação. Isso significa perder as referências mínimas que o enquadramento do real pela inteligência estabeleceu, e que se conservaram para o pensamento em sua aventura na história, na exata medida em que se tornaram indispensáveis para bem viver. Em suma, o mergulho na interioridade apaga as referências, e tomá-lo a sério como tempo real é a exigência para o tournant da filosofia. Num texto bem posterior ao Ensaio, Bergson retoma sua descoberta inicial, inicialmente sugerida pela imagem da melodia (mobilizada no primeiro livro, em várias ocasiôes) e ilustra a radicalidade dessa nova imagem do tempo: a melodia apenas sugere o passar do tempo, se tentarmos retirarlhe o máximo possível de determinaçóes, apagando as diferenças entre os sons, assim como as distinçóes interiores ao próprio som, conservando apenas a "[...] a transição ininterrupta, multiplicidade sem divisibilidade e sucessão sem separação, para encontrar por fim o tempo fundamental." (BERGSON, 2006, p. 53, grifo nosso).

\footnotetext{
${ }^{7}$ Em caráter introdutório, Arnaud François reúne os vários sentidos de intuição e suas principais ocorrências na obra de Bergson. Ver François (2008, p. 37-42).
} 
Ocorre que o aparente mistério da filosofia da duração só pode ser dissolvido, eis o fundamental, se essa pura fluidez puder ser conectada aos modos de ser que nossa inteligência distingue no real e sobre os quais ela própria está assentada - ou melhor, nos quais está implicada. Assim, na renovação bergsoniana, a solidez idealizada pela metafísica racionalista será atribuída à ciência, especialmente à física, como o seu lugar de direito, mas à filosofia caberá unir o sólido a algo que o ultrapassa e o condiciona. Eis o que queremos enfatizar: a emoção que se atinge pela intuição da nossa duraçáo nada significa para o conhecimento, sem que se esclareça como nossa experiência objetiva (e a realidade na qual se move, na qual agimos) com ela se conecta. É na relação incessante entre essa experiência profunda da duração como emoçáo criadora e as dimensóes concretas e objetivas da consciência intelectual e reflexiva (que é também nossa e define a nossa evolução como humanidade) que o método se estrutura em metafísica. Isso significa que não apenas a física, ciência dos sólidos e do movimento, em sua interface espacial, como a própria matemática não podem estar apartadas do oceano de vida que nos rodeia. A recuperação do papel da ciência, na metafísica bergsoniana, se evidencia a partir desses pressupostos, e uma ciência como a biologia (além, é claro, da psicologia, cuja função se deixa ver com nitidez no Ensaio, isto é, no encontro com a duração) desempenhará talvez o papel crucial no acompanhamento do movimento entre fluidez e concretude material no qual consiste a metafísica. A potente interpretação da intuição apresentada por Riquier nos oferece novos elementos para dar conta dessa dupla condição: distinguir o terreno da metafísica e da ciência pelo critério do contato com o movente, reunir as duas formas do saber através da intuição tomada em seu amplo espectro de atos cognitivos. Assim, se o autor contrapóe o fundir-se (do francês fondre), no todo pelo qual Bergson define a tarefa da filosofia, ao fundar-se (do francês fonder), no plano sólido que deve ser o projeto da física, ele demonstra, através de uma feliz diferenciação (a qual é também articulação) entre imagem e metáfora, que o fundamento só pode ser retomado pela metafísica como metáfora. A metafísica bergsoniana é das imagens, na medida em que estas não substituem a intuição ou o seu conteúdo, mas "[...] conduzem o filósofo ao ponto preciso em que uma intuição pode ser dar" (BERGSON, 2009, p.185); e essa metafísica apoiada nas imagens pode, então, ser relida como complemento essencial da física, ao instalar-se na "realidade movente" e, fluindo com ela, explorar "[...] de alguma forma o resíduo não sólido da matéria que a física teve que colocar fora de jogo. Da análise à intuição, do sólido ao fluido, há uma solução de 
continuidade que obriga a filosofia a saltar nesse novo elemento, do qual a água nos fornece a imagem evocadora." (RIQUIER, 2009, p. 50).

Para recuperar a origem dos núcleos sólidos que nos atravessam a matéria e a inteligência - a filosofia tem que romper com seus hábitos analíticos, naturais e discursivos, e saltar, num mergulho no obscuro, para assim retomar a continuidade entre o espírito e suas derivaçôes que lhe são antagônicas e complementares. Queremos enfatizar aqui o campo de fenômenos os quais nos são acessíveis e definem precisamente o que em nós é esse "fundo obscuro da duração", o que em nós permanece para além da objetividade constituída por nossa percepção e nosso entendimento, como sombra ou franja rodeando a luz da consciência reflexiva: as manifestaçóes da vida. ${ }^{8}$ É a vida a mediação entre a noite da duração e o dia ensolarado da consciência distinta, ou seja, é a vida o elo necessário para reconduzir espírito e matéria em sua continuidade e unidade, numa nova metafísica. E esse caminho começa (e retorna, quantas vezes for necessário) na consideração do sentimento difuso vivido por nós em nossa profundidade. Considerando esse papel da noção de vida e essa exigência da intuiçáo, não são poucas as dificuldades do percurso de $A$ Evolução Criadora que podem ser mais bem superadas. A relação que a teoria da vida estabelece com a biologia do século XIX aparece, então, seguindo as indicaçóes dessa leitura, como um caso específico do movimento próprio à intuição, movimento que mergulha uma espécie de sonda na profundidade obscura e dela retira pistas para recuperar os efeitos de superfície ali originados. Do sentimento que nos toma, a partir dos contatos fugazes com o todo no qual nos reinserimos, passamos à descrição do real em seus outros níveis, incluindo o da própria natureza e a ordem geométrica que o caracteriza. Da duração da consciência à duração real, a metafísica passa do psicológico ao biológico, do biológico ao cosmológico, por força desse vai e vem entre o profundo e o superficial, entre o sentimento confuso e a refração pelos dados "iluminados" da observação e da inteligência. A ênfase no papel do retorno à imersão na profundidade da duração no método evidencia a importância de retomar o reverso desse retorno em outros termos: os efeitos de superfície, articulados em fatos, formam os pontos de apoio para a intuição da duração, a

\footnotetext{
${ }^{8}$ É o que ressalta ainda Riquier, na bela contraposição entre o fundamento e o fundir-se: a noite obscura permanece ou está em nós como vontade e "alicerce afetivo da nossa consciência distinta", vontade e afetividade que "[...] nada são senão a vida que prossegue em nós... esses elementos permanecem em contato com o absoluto que nos habita, nos entregando o sentimento íntimo de sua profundidade, e é para eles que é preciso reconduzir a consciência." (RIQUIER, 2009, p. 51).
} 
materialidade própria ao conhecimento sobre a qual as sugestóes da intuição se concretizarão em metafísica. É na teoria da vida, enfatizamos, que a unidade múltipla da experiência sustenta essa comunicação, impedindo que a filosofia de Bergson recaia no dualismo epistemológico e ontológico em que uma duração diáfana é incomensurável com o mundo. Ao analisar a filosofia bergsoniana, buscando compreender a compenetração entre metafísica e método, Riquier aponta o papel e o valor do diálogo com a biologia no centro da terceira obra: trata-se de uma necessidade incontornável para Bergson, na medida em que não é possível passar da existência do eu à existência em geral sem o crivo da experiência objetiva. Bergson refere-se inúmeras vezes ao caráter vago e confuso de intuição interior, e podemos afirmar sem risco que a eficácia do método intuitivo depende da articulação entre o mergulho nesse oceano - de vida, como o filósofo sublinha - e as produçóes da observação e da inteligência que constituem os vários projetos científicos. O estudo da vida dará conta de um problema metafísico maior, o da criação como causalidade própria ao espiritual, tarefa que envolve essa etapa específica de refração do sentimento difuso pelos fatos: "[...] o estudo do movimento evolutivo permite ver explicitamente as virtualidades que se interpenetram confusamente em nós." (RIQUIER, 2010, p. 140, grifo do autor). A intuição como método de conhecimento, se é ato capaz de reencontrar em nossa consciência as potências da vida, seria identificada sem mais a um sentimento confuso, ilusório e misterioso, caso não obtivesse "[...] da análise e de sua aplicação aos fatos a clareza e a distinção desejadas." (RIQUIER, 2010, p. 140, grifo do autor). Retomaremos adiante essa lição essencial.

É importante acrescentar ainda algo não menos essencial: a fluidez indistinta não se afirma como único "conteúdo" acessado pela intuição. A dinamicidade da duração está articulada ou implicada em duas outras dimensóes que o aprofundamento da intuição revela gradativamente: a compenetração recíproca de tendências e sua direção ou intenção, uma vez que esse conjunto de tendências é, por assim dizer, "o que se movimenta" como impulso. O avanço de uma totalidade múltipla no real, nele se inserindo e com ele criando: essa apreensão da duração efetiva, em Matéria e Memória, o segundo livro do filósofo, o seu passo fundamental, pois ali se alcança o sentido do progresso da totalidade de tendências que somos, através do denso estudo do reconhecimento, que mostra a essência de nossa vida psicológica, num movimento de materializaçâo do imaterial direcionado 
pela vida. ${ }^{9}$ Assim, a progressiva exploração da duração vivida, trajeto que condiciona a sua compreensão como duração do real, acima e abaixo de nós, oferece-nos a apreensão do movimento de totalização incessante, avanço de uma totalidade aberta e dinâmica que é, de algum modo, estruturada. $\mathrm{O}$ vai e vem entre o fundo obscuro da duração e suas manifestaçôes como vida, natureza e criação depende, com efeito, de que seja possível distinguir na duração psicológica os traços pelos quais ela se elabora como totalidade, isto é, em fundo ontológico cujos níveis se estruturam nas realidades que nos envolvem. Implicados nesse fundo, memória e elã vital apresentamse como compenetração recíproca de tendências ou direçôes, elas mesmas atravessadas pelo movimento de avanço para o futuro que pressupóe a aproximação entre a duração e a ideia de vontade. Ao construir sua filosofia, Bergson pode passar da duração como sentimento à imersão no todo que nela está implicado, e essa passagem gira em torno das determinaçóes que os sucessivos livros acrescentam à melodia interior - especialmente as noçóes de tendência, totalidade e força. Enfim, dar conta de tal passagem significa atingir a criação própria à duração, distinta por natureza da criação pensada à luz do Nada. O coração da teoria da vida trará consigo as condiçôes dessa compreensão, como bem ressalta Bernet (2012, p. 27):

Toda tendência, tal como Bergson a encara, é entáo uma força que é a uma só vez enquadrada do exterior e estruturada do interior por suas virtualidades que salvaguardam seu poder criador e a protegem de uma realizaçáo cega e destruidora. É também por causa dessas mesmas virtualidades que o ser do movimento da consciência e da vida não pode ter nada (rien) em comum com um nada (néant) abissal. (grifo nosso).

Ressaltemos aqui uma dessas determinaçóes, a que se apresenta como direção ou intenção da vida. A intenção, como marca do espiritual, e a possibilidade de encontrarmos tal marca, como tendência ou direção, no que nos aparece (em nossa experiência ordinária) como exterior, são dimensões da intuição da duração trabalhadas por outro autor. Ao percorrer um trajeto

\footnotetext{
${ }^{9}$ Não retomaremos tal estudo, aqui, apenas algumas de suas conclusóes relevantes para nosso objetivo. Mas é fundamental lembrar que a experiência consciente e, assim, a própria noção de consciência são inteiramente redimensionadas por Bergson, nas duas primeiras obras, as quais devem ser lidas como um bloco, se quisermos tratar da consciência individual. Em suma, a aproximação entre vida e consciência, tese capital de $A$ Evoluçáo Criadora, é precedida e condicionada por esse potente estudo da vida mental anteriormente realizado. As direçốes essenciais da vida psicológica como memória em ato no mundo podem ser acompanhadas no "Resumée et Conclusion", de Matéria e Memória (BERGSON, 2008, p. 253-280).
} 
filosófico em que Bergson vem apenas acrescentar seu próprio tempero, David Lapoujade desenha um fio condutor em sua leitura da metafísica bergsoniana, o qual podemos seguir tomando como foco o ensaio sobre a intuição. ${ }^{10} \mathrm{~A}$ intuição da duração é para ele o encontro com uma emoção que não se resolve em afetos ou estados psicológicos dados no tempo (intratemporais), e a pergunta pelo tipo de emoção que ela é reporta-nos à ordem da energia espiritual que nos constitui e mesmo institui o duplo movimento que nos permeia, na medida em que "[...] de um lado se acumula nas profundezas do eu, de outro, explode num ato livre.” (LAPOUJADE, 2010, p. 22). Sua leitura de Bergson estabelece um novo vínculo entre tempo e afeto, justamente ao retomar a profundidade do eu como núcleo ontológico a partir do qual a noção de experiência se transforma. A fluidez ou mobilidade essencial da duração se deixa apreender por uma emoção que nos afasta do modo comum pelo qual nos relacionamos aos seres, às coisas (e mesmo aos "nadas"): trata-se da emoção da passagem do tempo, "afeto que não é mais apego" (LAPOUJADE, 2010, p. 24), único ponto de partida para que possamos apreender os movimentos, em nós e nas coisas. Por ela e somente com ela podemos nos reencontrar como vibraçóes, pulsar incessante que somos, e a filosofia se construirá pelos sucessivos retornos a essa interioridade outra e às suas ligaçóes com os movimentos que povoam a nossa superfície e o mundo no qual vivemos (nossa vida, nosso universo). Ocorre que esse viés de leitura retoma novamente a noção de experiência, eis o que nos chama atenção, levantando hipóteses para adentrarmos na enigmática definição de metafísica (ou possibilidade de definição, para repetir a afirmação explicitamente) como "experiência integral" (BERGSON, 2009, p. 227). Assim, trata-se de seguir as direçóes que a dimensão profunda de nossa experiência sugere, e com ela compreender as liçóes extraídas do enquadramento intelectual do real, isto é, da superfície da consciência em incessante processo de espacialização:

É nesse sentido que há dois lados da experiência em Bergson, o lado da inteligência, vasto plano superficial onde tudo se desdobra horizontalmente

\footnotetext{
${ }^{10}$ Se Archeologie du temps se debruça em sua totalidade sobre a metafísica renovada como método, a reunião de ensaios que conforma Potências do Tempo pode ser lida a partir da eleição do capítulo sobre a intuiçáo como seu centro. A despeito de que as duas propostas apresentam diferenças cruciais, a começar pelo âmbito que a filosofia de Bergson ocupa, em seus trajetos filosóficos, é fundamental apontar duas vertentes nas quais os autores se encontram: a primeira, terem levado a sério a leitura de Deleuze, a ponto de encontrar efetivamente os seus limites; a segunda, ligada à primeira, terem construído suas hipóteses de interpretação com base na incorporação, rara nos estudos bergsonianos de fôlego, de As Duas Fontes da Moral e da Religiāo como etapa constitutiva do corpus teórico que começa com o Ensaio e percorre Matéria e Memória e A Evolução Criadora.
} 
no espaço, segundo a lógica da representação. E o lado da intuição ou da emoção profunda, um mundo vertical onde tudo se organiza em profundidade, segundo uma pluralidade de níveis ora inferiores ora superiores ao da inteligência, mas sempre paralelos a ele, operando segundo uma lógica de outra natureza. (LAPOUJADE, 2010, p. 10).

Interessa-nos especialmente, nessa outra chave de interpretação do bergsonismo, para nós estritamente complementar à de Riquier, suas consequências para a compreensão da intuição das outras realidades, fora de nós, em particular para o conhecimento da vida. Nesse contexto, a emoção criadora e seu "número obscuro" iniciam a leitura que aponta na noção de simpatia o complemento indispensável à intuição e desenvolve consideraçóes esclarecedoras sobre o papel dos fatos no tipo de analogia que a intuição bergsoniana procederá, via simpatia, possibilitando que encontremos o espiritual no vital. A relação entre intuição e simpatia esclarece o acesso à unidade dinâmica de um múltiplo, que só se deixa compreender como unidade de um todo. Assim, é a redescrição das dimensóes ou níveis do real como movimentos em totalização que realiza o ideal metafísico postulado pela filosofia da duração. A duração, outro nome do espírito, deve caracterizar aquilo que em nossa experiência nos aparece como exterior, anterior e que nos envolve. Mais explicitamente, a intuição é o método filosófico que permite alcançar a essência interior do real como espírito ou duraçáo, e o trabalho filosófico de Bergson proporciona a superaçáo de nossa percepçáo parcial das coisas para o conhecimento interno das mesmas - o conhecimento do que nelas é sua própria interioridade. Essa interioridade dos objetos é o que Lapoujade bem esclarece como seu sentido interno ${ }^{11}$, cuja compreensão depende justamente de que nosso conhecimento passe da duraçâo do sujeito à duraçâo dos objetos. $\mathrm{O}$ autor nos esclarece então sobre o papel da simpatia, prolongamento da intuição enquanto forma de captaçáo

11 O real é um todo unificado dotado de direção interna; sua natureza se deve ao ato de contração da memória, sobre o qual se funda a continuidade interior do real. O comentário de Lapoujade sobre a simpatia, definitivo em nossa opiniáo, tem o grande mérito de lançar luz sobre o método intuitivo, ao atribuir à simpatia o papel de apreensão da intenção ou direção que unifica uma realidade como todo. Ao fazê-lo, a simpatia proporciona à intuição apreender esse todo como duração. Essas consideraçóes são essenciais ao estudo da vida e, nesse sentido, à passagem da psicologia à cosmologia bergsoniana. Assim, "[...] se o todo deve sua natureza de todo a uma certa memória que garante a continuidade interior de que ele é feito" (LAPOUJADE, 2013, p. 52), essa memória identifica-se a uma direção ou intenção "constitutiva do seu sentido". Ora, a intuição realiza seu trabalho, quando é capaz de apreender qualquer nível do real como duração, porém, para tanto, necessita do trabalho da simpatia, à qual cabe "[...] apreender a intençấo interior a essa duraçăo." (LAPOUJADE, 2013, p. 53). 
do real como espírito: intuiçẫo e simpatia não significam a mesma coisa, mas se complementam como aspectos do método filosófico: "[...] tão logo o espírito apreende outras realidades, a relação se torna necessariamente indireta. É aqui que ele precisa prolongar-se em simpatia." (LAPOUJADE, 2013, p. 56). Desse modo, ao tratar do vital, o filósofo deve encontrar, para além da sua aparência exterior que induz à decodificação dos seres vivos como organismos adaptados ao meio, o movimento essencial da vida - movimento invisível, cujos fragmentos visíveis estáo em nosso horizonte de observação e, como sinais ou pistas, podem nos conduzir à sua apreensão - isto é, o seu sentido. A vida é compreendida como duraçáo, na exata medida em que encontramos sua essência como ímpeto interior de criação, e o denso trabalho teórico de análise dos fatos da biologia levado a termo em $A$ Evolução Criadora, pelo qual se atinge tal compreensão evidencia o papel da simpatia. Dessa forma, se o conhecimento absoluto do real articula a vida como movimento de criação de organismos que acentuam tendências (pelas quais se definem propriamente as espécies) e a gênese da materialidade como inversão do movimento de tensão que está no coração da criação dos mundos, ou seja, articula a criação no nível biológico com a criação cosmológica, a intuição da vida deve apreender a essência da vida, isto é, o seu sentido. Retomar o movimento da vida e atingir a sua essência como libertação (inserçâo da liberdade na necessidade) identifica-se, pois, a apreender a sua direção, a sua intenção:

[...] graças à simpatia a vida torna-se "sujeito" para a metafísica (como espírito ou consciência), enquanto permanece "objeto" para a ciência (como material físico-químico). A simpatia desempenha aqui um papel essencial: ela separa a "intenção" propriamente espiritual do vital, permitindo assim constituí-lo em tendência-sujeito no interior da metafísica. Ao mesmo tempo, ela parece torná-lo acessível à intuição. (LAPOUJADE, 2013, p. 54).

A teoria da vida ou, como Bergson a identifica, o "estudo do movimento evolutivo", buscará, com efeito, delimitar as linhagens de espécies que explicitam tendências dominantes e, combinando as tendências entre si, delinear a imitação "[...] do princípio motor do qual procedia o seu elã.” (BERGSON, 2007, p. 102). Logo, se a duração que vivemos em nós se dá numa experiência da multiplicidade de interpenetraçáo, a vida que se apresenta a nós por seus produtos ou formas visíveis indicará nessa duração um movimento de criação, uma força que age no mundo como corrente. A passagem para o estudo da vida, antecedida pelo denso e original 
estudo do passado, na segunda obra, permite a Bergson compreender a vida como memória e, por isso mesmo, o movimento evolutivo como corrente de consciência:

Em suma, as coisas se passam como se uma imensa corrente de consciência, em que se interpenetram virtualidades de todo tipo, tivesse atravessado a matéria para encaminhá-la à organização e para fazer dela, ainda que ela seja a própria necessidade, um instrumento de liberdade. (BERGSON, 2011, p. 19).

\section{METAFÍSICA E CIÊNCIA: UMA NOVA ALIANÇA NA EXPERIÊNCIA ${ }^{12}$}

O estranhamento em relação ao projeto bergsoniano de renovação da metafísica assume implicitamente as direções que a tradição filosófica determinou para qualquer teoria do ser, em especial, a via da abstração. Uma teoria geral da existência, ou o conhecimento do Todo, náo escapa à abstração - eis o postulado que será rebatido e superado por uma metafísica que se quer concreta. ${ }^{13}$ Todavia, justamente porque se trata, no bergsonismo, de uma "[...] inversão da direção habitual do trabalho do pensamento" (BERGSON, 2009, p. 214), de uma superação do que nos determinou como espécie e possibilitou-nos a sobrevivência, isto é, o desenvolvimento e boa parte das transformaçóes pelas quais passamos e assim evoluímos - a inteligência - é que ele pode propor o retorno ao projeto da metafísica, escapando da poderosa (e justa) crítica kantiana. Em outros termos, é indispensável ter em mente, para dar conta do que Bergson entende por teorias intuitivas, que a metafísica renovada enfrenta as vastas especulaçóes, através de uma investigação positiva e inseparável da nossa experiência, subjetiva e objetiva, e isso na exata medida em que se desenvolve como nova figura do espiritualismo. Para tanto, tem necessariamente que encontrar as condiçóes de possibilidade de uma teoria geral que náo incorra nos

\footnotetext{
${ }^{12}$ A expressão "nova aliança" é utilizada por Riquier em seu livro, mas se tornou marco de uma nova perspectiva sobre as relaçôes entre a ciência e a cultura, a partir da obra de Stengers et Prigogine, $\mathrm{La}$ Nouvelle Alliance (pode ser consultada a versão brasileira Prigogine e Stengers, 1997). É importante lembrar que Prigogine escreveu um livro assumindo a influência de Bergson em alguns pontos precisos de sua reflexão sobre o tempo. $\mathrm{O}$ uso dessa expressão reforça o viés que perseguimos desde sempre, em nossos estudos, a relação entre ciência e metafísica como dimensão relevante e original da filosofia bergsoniana - ver Prigogine (1992).

${ }^{13}$ Nesse âmbito, as acusaçōes centradas no suposto retorno "pré-crítico" de Bergson assumem a crença na implicação indissociável entre metafísica e abstração: não se vê como seria possível tratar dos temas mais caros à especulação filosófica, sem proceder à generalização que se distancia inelutavelmente do solo da experiência humana, da sensibilidade e do terreno dos fatos.
} 
equívocos da abstração; em suma, precisa desvincular o geral do abstrato. Os argumentos retomados e sintetizados em "Introdução à Metafísica", aliados à consideração efetiva dos sentidos implicados entre si na noção de intuição, permitem enxergar como a teoria da vida desenvolvida na obra A Evolução Criadora alcança esse objetivo, dar conta da existência em geral, sem se afastar do âmbito dos fatos, revelando-se como pilar do empirismo superior postulado pelo filósofo. Ao movimentar-se entre a profundidade da duração (em diversos graus de tensão e distensão) e a superfície de nossa experiência (e seus distintos planos de objetivação), a metafísica não só nos introduz aos diversos níveis do real (cuja unidade é múltipla, dinâmica e heterogênea), como também mobiliza diferentes graus de conhecimento. Ciência e metafísica não se encontram, então, de um único modo, mas conhecem variados e múltiplos encontros conforme o objeto preciso em torno do qual a filosofia se estrutura. O conhecimento é ele próprio um movimento que perpassa diversos níveis, e seus extremos podem ser tomados como limites ideais entre o que concretamente os maiores avanços na história do conhecimento realizaram: "[...] entre as matemáticas que seriam o simbólico puro e o misticismo que seria o intuitivo puro, haveria lugar para uma multiplicidade de ciências repartidas em função da dosagem variável que elas suportam entre a análise e a intuição.” (RIQUIER, 2009, p. 88).

Nesse contexto, o final da conferência surge como um dos textos mais relevantes para nossos propósitos. É ali que se situa a afirmação que sublinhamos no início deste texto: a diferença entre as teorias intuitivas e as metafísicas da modernidade (cujo ápice é, paradoxalmente, a crítica kantiana) repousa na superação de um equívoco estrutural. Tais metafísicas retiram do real - pura mobilidade - vistas parciais que se concretizam, pela elaboração analítica na qual se fiam, em teses e antíteses. Reportando-as à sua origem, esse todo movente do qual elas desviaram seu olhar, o novo modo de conhecimento do real compreende inclusive como dele se derivam as antinomias, desde que se busca expressá-lo em conceitos, o que é inevitável à filosofia. Retornamos aqui, agora mais bem esclarecidos, à relação entre o impulso originário - intuitivo - de uma filosofia e sua inevitável materialização em obra discursiva - analítica - relação que mencionamos na abertura deste texto. Dessa forma, a disputa entre as escolas tem sua razão de ser no esforço discursivo da filosofia, e cabe à metafísica intuitiva devolver a esse esforço sua própria gênese. Ao fazê-lo, a investigação filosófica pode demonstrar que elas trabalham, sob presidência da análise, sobre os materiais obtidos pelos lançamentos de uma sonda (no oceano da duração) e trazidos à superfície, onde serão talhados e divididos, articulados e rearticulados 
em obras do entendimento. Pelo contrário, é sobre o ato originário que o metafísico deve se basear. Ele se realiza como ato de uma faculdade, a da intuição, que não se deixa compreender pelas análises, mas nem por isso configura uma espécie de mistério. É fundamental ressaltar o argumento de Bergson, aqui: esse "mistério" é facilmente esclarecido, através da analogia com a composição literária, num ponto preciso: o escritor é capaz de, uma vez tendo frequentado, em ampla extensão, os sinais concretos sobre o que está escrevendo, tendo estudado longamente o seu tema e obtido "documentos recolhidos, notas tomadas" (BERGSON, 2009, p. 225), dar um passo a mais, o ato de composição por excelência, isto é o "esforço penoso" pelo qual ele se transporta de um só golpe e nele busca "[...] uma impulsão à qual depois bastará se deixar levar.” (BERGSON, 2009, p. 225). A criação literária é, desse modo, uma composição que parte da frequentação de materiais visíveis e concretos, contudo, apela a uma impulsão que unirá e constituirá a obra, pois conduzirá o espírito por entre os materiais que acumulou, levando-o inclusive a distinguir e enumerar outros. $\mathrm{O}$ esforço que se instala de imediato no vivo da questão é como que um salto, o qual considera e atinge um impulso, ou melhor, uma impulsão que "[...] se analisa a si mesma em termos cuja enumeração se seguiria infinitamente.” O que essa analogia sugere sobre a intuição? Que ela também implica um salto e atinge um impulso, porém, partindo de um trabalho de "documentação", de caminhada no concreto - e eis o ponto que nos é essencial: o que corresponderia aqui às notas e documentos seria "[...] o conjunto de observaçóes e experiências colhidas pela ciência." Tal conjunto é a contrapartida do impulso unificador, "[...] a reflexão do espírito pelo espírito." (BERGSON, 2009, p. 226). Se a intuição filosófica se efetiva como uma composição literária, ela se apoia e se orienta por duas dimensóes da experiência, a objetiva, que a ciência aperfeiçoa e sistematiza, e a subjetiva, que envolve a nossa apreensão como espírito, isto é, como duração. A citação à qual Lapoujade soube conferir a devida importância fecha a analogia, de maneira elucidativa:

Não se obtém da realidade uma intuição, isto é, uma simpatia espiritual com o que ela tem de mais interior, se náo se tiver conquistado a sua confiança por uma longa camaradagem com suas manifestaçóes superficiais. E não se trata simplesmente de assimilar os fatos marcantes: é preciso acumulá-los e fundir conjuntamente entre si uma massa tão grande deles que estejamos assegurados, nesta fusão, de neutralizar umas pelas outras todas as ideias preconcebidas e prematuras que os observadores tenham colocado, sem perceber, no fundo de suas observaçóes. Só assim se isola a materialidade bruta dos fatos conhecidos. (BERGSON, 2009, p. 226, grifo nosso). 
A intuição que se movimenta entre os diversos graus da duração e é capaz de conhecer em si mesmos os objetos - tem um impulso inicial, a apreensão de si por si, como criação de si por si, mas, mesmo nessa etapa originária, ela não dispensa os conhecimentos materiais, exigindo que o contato do eu consigo mesmo esteja suportado por uma série de análises psicológicas. No caso da cosmologia, o conhecimento da natureza em si no que tem de essencial, ela só pode conformar um conhecimento absoluto, por intuição, e assim cumprir uma etapa metafísica primordial, se estiver apoiada no imenso número de fatos circunscritos pelo trabalho da ciência. A intuição não é a análise, a metafísica não é a ciência, todavia, ambas não se efetivam sem o seu complemento. E é esse trabalho com os fatos que permite, paradoxalmente, que o sentimento confuso vivido subjetivamente na imersão em nós mesmos possa ser desdobrado em conhecimento claro, objetivo e, logo, efetivamente realizado. ${ }^{14}$ É desse sentimento que vem o impulso da intuição e, sem ele, os dados visíveis não encontram sua articulação, sua unidade; da análise ou da síntese dos conhecimentos materiais não resulta esse impulso, mas, sem essa materialidade, o impulso paira no vazio. Se a metafísica pode, como afirma Bergson, no epílogo da conferência, ser definida como experiência integral, é precisamente no sentido de que ela conjuga a materialidade dos fatos e a impulsão que os atravessa, unindo as duas observaçóes ou, antes, a apreensão subjetiva e a visada objetiva. Esse é o meio e o modo de incorporar potências complementares à inteligência: não mais obra da pura razão ou, em termos bergsonianos, da inteligência espacializadora que procede à solidificação do movente, a metafísica exige a superaçáo da forma propriamente humana de conhecer, fundada e desenvolvida à luz da ação e, nesse sentido, demanda uma torção ou ruptura como único modo de atingir o absoluto que vive em nós. $\mathrm{O}$ conhecimento passa a ser, então, obra do espírito, envolvendo a espiritualidade integralmente, não mais parcialmente, segundo as funçôes da consciência exteriorizada e modelada pela matéria inerte. Ora, essa recuperação do que é frequentemente indicado por Bergson como nebulosidade, franja, sugestão de direção ou sentimento vago e difuso não prescinde da inteligência. Pelo contrário, trata-se de encontrar o fundo a partir do qual a consciência se limitou em inteligência, que se identifica ao princípio cuja inversão de sentido, num movimento para além de nós, se degradou em materialidade.

Tudo se joga, pois, na nova filosofia da natureza que se esboça em sua obra. Sem encontrar as raízes do dinamismo na natureza, isto é, sem

\footnotetext{
${ }^{14}$ Conforme a citação de Riquier sobre a clareza e a distinção, transcrita anteriormente.
} 
detectar propriedades como a fluidez e a heterogeneidade no ambiente já mapeado, com sucesso, por uma física que em tudo encontra a fixidez, a homogeneidade e a repetição, não há superação da duração psicológica e encontro de um absoluto, o qual, mesmo vivendo em nós, nos antecede e nos condiciona. Essa empresa, realizada em A Evolução Criadora, só obtém êxito na medida em que a duração real é apreendida em sua relação intrínseca com a matéria. A cosmologia deverá não apenas conciliar as propriedades definidas pela física com as características, no mais das vezes a elas opostas, da duração interior, como também demonstrar que algo na natureza procede à criação de si por si - esse algo é a vida. É o elã vital, enquanto imagem do movimento que a um só tempo atravessa e permeia a matéria, o qual fundará a duração na natureza. Aqui, método e doutrina efetivam o seu encontro crucial: a duração na natureza se descobre por uma investigação que perscruta sentimento interior e espraiamento exterior, apreensão subjetiva inseparável da visada objetiva. Se o todo é interiormente criação, portanto, Vida, isso se constata precisamente pelos conjuntos de fatos que configuram o movimento da vida em composição com a matéria, para promover a indeterminação e a liberdade. É no biológico que a passagem se efetiva, e a consideração dos fatos desempenhará seu mais relevante papel nesse momento da obra de Bergson.

A nova aliança entre metafísica e ciência é um objetivo declarado (em várias ocasióes, acrescente-se) de Bergson: elas devem realizar juntas o conhecimento absoluto do real, e essa realização depende em larga medida do desenvolvimento de um método cuja maturidade só podemos encontrar em $A$ Evolução Criadora. A terceira obra do filósofo nos apresenta tanto os termos mais completos em que a intuição da duração se transforma em conhecimento objetivado, quanto - e por conta desse estágio metodológico atingido - a apreensão da unidade dinâmica da natureza, isto é, o núcleo da metafísica espiritualista que deve dar conta da relaçáo intrínseca entre espírito e matéria, de um ponto de vista cosmológico e não mais apenas no caso do homem. Desse modo, unindo matéria e espírito, por meio da tese de que o movimento de tensão do espírito se inverte de si mesmo e se estende em materialidade, a metafísica pode rearticular ciência e filosofia, delimitando os seus respectivos campos e devolvendo à ciência o alcance que lhe é próprio, mas que foi encolhido pelo seu progresso e concomitante esquecimento de sua origem. Ao voltar-se sobre o seu percurso e extrair-lhe consequências não formuladas até então, Bergson resume magistralmente o que alcançou, através da intuição da duração: 
Assinalamos entáo à metafísica um objeto limitado, principalmente o espírito, e um método especial, antes de tudo a intuição. Por aí distinguimos nitidamente a metafísica da ciência. Mas por isso mesmo nós lhes atribuimos igual valor. Nós acreditamos que elas podem, uma e outra, tocar o fundo da realidade. Nós rejeitamos as teses sustentadas pelos filósofos e aceitas pelos cientistas sobre a relatividade do conhecimento e sobre a impossibilidade de atingir o absoluto. (BERGSON, 2009, p. 26, grifo nosso).

Essa maturação de um modo de conhecimento supraintelecutal, que acaba por ultrapassar limites claramente definidos para a razão em seu uso especulativo, não invalida ou diminui os resultados obtidos pelo Ensaio sobre os dados imediatos da consciência e por Matéria e Memória; ao contrário, acaba por lhes ampliar o escopo e extrair-lhes consequências, bem como esclarecer pontos que permaneceram abertos, em algumas de suas formulaçôes. Em todo caso, trata-se aqui de sublinhar em que dimensóes da intuição o terceiro livro avança muitos passos, concomitantemente ao desenvolvimento de seu principal resultado, o próprio "acabamento" da metafísica da vida. Do ponto de vista metodológico, encontramos no bloco formado pelos dois capítulos centrais do livro uma articulação entre apreensão subjetiva e visada objetiva, as quais as duas obras anteriores apenas anunciaram. Tal articulação não se situa em definitivo em cada um dos capítulos, mas permeia tanto a relação entre a análise da evolução vital (a interpretação propriamente filosófica do campo biológico, estrito senso) e a filosofia da natureza que a funda num movimento que se inverte de si (isto é, a explicação do mundo e da ordem física à qual ele tende), quanto à elaborada construçáo da cosmologia, por um movimento teórico pendular entre, de um lado, o que sentimos como tensão e extensão, criação e distensão e, de outro, a prova de que esse movimento explica o real em sua dupla forma. Se a intuição nos oferece, enquanto experiência profunda de si, um sentimento, a sua fertilidade depende de que ela se articule com o centro luminoso do conhecimento que Bergson reconhece estar na inteligência:

A inteligência permanece o núcleo luminoso em torno do qual o instinto, mesmo ampliado e depurado em intuição, não forma mais que uma nebulosidade vaga. Mas na falta de conhecimento propriamente dito, reservado à pura inteligência, a intuição poderá nos fazer apreender o que os dados da inteligência têm aqui de insuficiente e nos deixar entrever o modo de completá-los. (BERGSON, 2007, p. 178). 
Sem pretender aqui esgotar o sentido dessa afirmação, nem no que ela tem de produtivo, nem no que apresenta de problemático, retomamos a passagem pela importância para a reflexão sobre a vida como "objeto" especial que torna possível a compreensão da natureza total, em sua unidade dinâmica. A sugestâo que se insere nos dados recolhidos pela ciência desenha o movimento da vida por entre as espécies, ao mesmo tempo em que avança esclarecimentos sobre as próprias conquistas dos biólogos e lhes atribui um valor de verdade antes não equacionado. $\mathrm{O}$ que a biologia diz da adaptação, da sobrevivência e da relação entre as espécies, em sua distribuição no mundo, não só está bem fundado, como expressa resultados do movimento que está na sua origem. As interpretaçôes em círculos, as más ambiguidades e alguns dos impasses impeditivos recebem dessa sugestão intuitiva vias de solução, e podem ser mais bem incorporados por uma visada global, que restabelece a interdependência entre fenômenos cuidadosamente observados e, logo, compreende seu sentido mais profundo, a sua temporalidade própria. A cosmologia e, mais profundamente, a metafísica poderão dar conta da dupla forma do real, na exata medida em que a inteligência reconhece seus limites, sua adequação de fato e de direito à matéria, e libera a filosofia para recorrer sem constrangimento à intuição, precisamente essa capacidade de conhecimento afinada em natureza com a vida. É o que Bergson quer dizer, quando afirma que a metafísica depende da teoria do conhecimento e só pode levar sua tarefa a cabo, se puder "[...] espremer a ambas (intuição e inteligência) para delas extrair a quintessência de seu objeto." (BERGSON, 2007, p. 179). Enfim, é em torno da vida que tudo gira, e o percurso nuclear a essa nova metafísica depende de que se possa fazer a passagem do bios ao cosmos, da vida do organismo ao mundo físico permeado pela vida - agora compreendida como esforço para retardar a degradação da energia criadora em matéria.

\section{INTUIÇÁO E CRIVO DOS FATOS - A BASE CONCRETA DA NOVA METAFÍSICA}

Entretanto, como tais indicações surgem in vivo na obra? Como dissemos acima, é o bloco central do estudo da vida o momento mais revelador a esse respeito. Se é bem nessa etapa da filosofia de Bergson que o método parece tomar consciência de si, ou antes, se efetiva como conhecimento propriamente metafísico, isso envolve tanto o aprimoramento do mergulho interior, o qual busca nas profundezas da consciência a duração e seus movimentos internos, quanto a refração do que é assim sugerido ao sujeito filosofante, por intermédio dos fatos objetivamente circunscritos e sistematizados pela ciência. É, de fato, 
em $A$ Evolução Criadora, que a incorporação das teses científicas criticadas e situadas, aliada à mudança de perspectiva do olhar que incide sobre os dados da biologia, ganha sua feição mais definida e seus efeitos mais produtivos. Bergson nos adverte com clareza sobre a importância desse trabalho que repercute no próprio terreno da ciência, uma vez que a releitura filosófica da biologia, encaminhada pela intuição, desembaralhará a confusão advinda da decisão de abandonar inteiramente à ciência positiva a "consideração dos fatos" (BERGSON, 2007, p. 195). Se a filosofia recebe da ciência os fatos já circunscritos pela inteligência, faculdade de agir e se saber agir, ela se limitará a formular com mais precisão uma teoria de âmbito metafísico, cujas direçóes essenciais estão implicadas no labor científico:

Por náo ter desejado interferir, desde o início, nas questôes de fato, o filósofo se encontra confinado, nas questôes de princípio, a formular pura e simplesmente em termos mais precisos a metafísica e a crítica inconscientes, portanto, inconsequentes, que a própria atitude da ciência desenha face à realidade. (BERGSON, 2007, p. 196).

Nesse contexto, a leitura do segundo capítulo do livro, em que a intenção da vida é recuperada, com base nos sinais concretos que os organismos e espécies representam em relação ao movimento que lhes deu origem, acaba por trazer alguma luz para uma vertente da filosofia bergsoniana que sempre nos foi muito cara: a articulação entre os supracitados sentidos distintos de experiência, a que nos é profundamente interior, e a que se constitui em nossa exteriorização, superficialmente, configurando o campo dos fatos por uma objetivação que, tomada em seu processo (e náo mais como coisa, mundo ou campo do possivel), explicita o próprio movimento de materialização do espiritual, ou de espacializaçáo do tempo. A descrição bergsoniana do movimento evolutivo retoma, a partir das justificativas filosóficas amplamente desenvolvidas na elaboração da teoria do elã vital ${ }^{15}$, a multiplicidade qualitativa e a memória pura como figuras da totalidade de interpenetração, implicação recíproca de tendências que quer ser, isto é,

\footnotetext{
${ }^{15}$ A teoria é elaborada no primeiro capítulo de $A$ Evolução Criadora, pela intenção definida em sua abertura: investigar se a existência em geral pode ser compreendida tal como a nossa existência. Bergson nos esclarece que é somente pela mediação da vida, criação na natureza, que se pode alcançar o conhecimento absoluto do real, o que inclui a materialidade como duração. Ali também encontramos os principais argumentos para a leitura do transformismo, depurado dos equívocos do mecanicismo e dos excessos do finalismo, como verdade da história das espécies. Sobre o elã vital, permitimo-nos enviar o leitor ao texto: Pinto (2009, p. 381-396).
} 
avançar e desdobrar-se em abertura constante ao seu outro - a materialidade. Essa retomada é, portanto, confrontada com os fatos evolutivos e deles recebe, além de sua raiz na natureza, a derivação de consequências metafísicas cujo núcleo é a vida em sua empiria, e cujo alcance é a justificação filosófica da tese segundo a qual criação é a essência última da durée. No que tange à metafísica, o procedimento de elaboração do material empírico exige, em parte, desconstruir o enquadramento que força os dados, ao aplicar-lhes categorias exteriores, as mesmas que nossa inteligência aplica ao real em sua função prática e natural, e, em parte, reinseri-los em relaçôes das quais foram afastados por esse enquadramento. Isso não significa renegar teses e sistematizaçóes de observaçóes que fizeram a fortuna do evolucionismo. Bergson jamais recusará, por exemplo, a evidência de que as espécies se distribuem no espaço do mundo segundo os ditames da adaptação. Mas a distribuição no espaço é insuficiente para dar conta da evolução no tempo, isto é, do processo de mudanças - ou mutaçóes, para usar o termo assumido pela ciência - pelas quais os organismos se transformam e, assim, surge a novidade. O processo de diferenciação, aqui, desemboca nos indivíduos novos que derivam em grupos com significativa capacidade de adaptação. Bergson pretende, ao preencher as lacunas que os evolucionistas deixam em suas explicaçóes, oferecer uma boa hipótese sobre a causa profunda das transformaçôes. Em linhas gerais, elas se devem à origem comum das tendências que os grupos de espécies carregam em sua identidade. A tendência vegetal e a tendência animal, por exemplo, surgem em grupos adaptados em regióes distantes e numerosas e, a despeito de sua imensa variedade, encontramos em vegetais e animais caracteres que possibilitam à nossa inteligência agrupá-los segundo um traço marcante. Essa visibilidade permite intuir a relação divergente e complementar entre os dois grupos, relação que deve expressar, por seu turno, o todo que lhes subjaz - sua memória. Vejamos a seguir, em detalhe, como se processa esse movimento do texto bergsoniano.

A ideia geral da evolução, a qual resulta do trabalho crítico sobre as duas interpretaçóes excessivas para o fato inelutável da transformação das espécies - mecanicismo e finalismo -, não indica apenas, na evolução vital, um movimento que avança criando novas formas; ela impóe também a compreensão de que esse movimento dissocia tendências originariamente implicadas entre si. A noção de totalidade dinâmica de interpenetraçáo, essa mesma à qual a multiplicidade qualitativa da duração nos introduziu, trabalha como "pressuposto" do acesso aos fatos que fundamentará a tese que aproxima vida e consciência. Aqui cabe uma ressalva: no fazer filosófico 
de Bergson, o que se configurava como pressuposto na leitura espacializadora dos fatos transforma-se em sugestão e, nessa mudança, reside o ponto crucial da diferença no tratamento dos dados de nossa experiência objetivada. A totalidade de interpenetração trata-se assim, na verdade, do "conteúdo" da intuição anteriormente atingido, e agora recuperado em suas sugestóes para a compreensão da vida. A aproximação ou identificação entre vida e consciência, retomando as dimensôes da consciência humana como memória, consiste precisamente no momento em que Bergson encontra a base concreta a partir da qual deriva a tese nuclear do livro, a de que o real comporta em si a criação. Há uma elaboração especial dos dados da ciência, que se pode supor perfeitamente passível de ser adotada pelo trabalho dos cientistas, em que se procura desvelar as linhas de fatos - talvez fosse mais adequado falar em "redes de fatos", mas seria propor uma nova formulação, ausente dos textos aqui examinados - elaboração que marca o ponto de convergência entre ciência e metafísica, no qual se concretiza a intuiçáo, conforme vimos acima.

Em outros termos, assistimos, tal qual um espetáculo se descortinando paulatinamente na relação com a biologia que estrutura o segundo capítulo do livro, a como a nova aliança entre metafísica e ciência nos convida a lidar com os fatos em conjuntos significativos e, portanto, como a intuição invade o trabalho da ciência e traz para a metafísica seu solo efetivamente concreto. Nesse espetáculo, vemos a experiência da duração, interior e subjetiva, em confronto e articulação com as análises objetivas que a ciência foi capaz de construir, em séculos de trabalho, a despeito de seus recuos, confrontos e superaçóes intermináveis. Como bem enfatizou Lapoujade, a intuição da vida é tributária da apreensão do sentido através dos signos, isto é, a intenção do movimento vital pode ser encontrada pela interpretação náo espacializante dos organismos e espécies em sua história e distribuição na natureza. Assim, nós simpatizamos com a vida. E, o que queremos sublinhar, a forma de mobilizar os dados é o ponto crucial para que a experiência em seu sentido objetivo cumpra seu papel numa metafísica que abre mão do fundamento e persegue o real, em seu movimento de efetivação.

Busquemos explicitar o viés que a análise da evolução das espécies tomará: trata-se de observar os dados da biologia e as linhagens nítidas de organismos em sua relação complementar - ou melhor, encarar "[...] os resultados divergentes da evolução não mais no que eles apresentam de análogo, mas sim do que tem de mutuamente complementar." (BERGSON, 2007, p. 98, grifo nosso). Insistamos no peso dessa expressão: os fatos ou conjuntos 
de observaçôes não são peças que compóem um mosaico, não são átomos ou partes de uma estrutura que se desmonta e se remonta segundo a lógica da fabricação própria à inteligência. Eles devem ser seguidos em seu movimento próprio, apreendidos em relação, temporalizados e não mais espacializados. No enquadramento espacial, o divergente é pura oposição, sem comunicação ou passagem que se possa alcançar. Essa mudança de olhar sobre os dados biológicos se efetiva concretamente, através de referências ao trabalho empírico dos cientistas da evoluçáo, tanto nas análises das linhagens de organismos e espécies quanto no trabalho que antecede tais análises e é sua condição de possibilidade: a elaboração da hipótese do elã vital como linha mestra do transformismo. Essa elaboração apoiou-se também nos exemplos precisos, recuperando debates da ciência em torno da presença de órgãos semelhantes em linhagens divergentes, e mostrou com nitidez que nem mecanicismo, nem finalismo são capazes de nos oferecer a descrição fiel do processo evolutivo. O primeiro capítulo do livro trata, por conseguinte, de limpar o terreno para que a vida seja compreendida como corrente que atravessa os organismos e avança apoiada neles. ${ }^{16}$ A corrente que atravessa organismos e espécies passa de dissociação de um movimento para desdobramento de tendências originariamente implicadas num todo, e tal passagem efetiva a explicitação do significado do elã vital como corrente de consciência. Consciência e memória são entrelaçadas intimamente, pelo percurso de Matéria e Memória. Esse vínculo está operando agora na teoria da vida: a relação complementar tem seu fundamento precisamente na tese de que o desenrolar das espécies parte de um fundo único e, por isso mesmo, se trata da concretização material de um conjunto de tendências cuja origem é comum. Em síntese, o mutuamente complementar é apenas a expressão de que o elã vital é uma memória em ato no mundo, e aquilo que as tendências dominantes do movimento vital têm em comum consiste no seu passado.

Ao recolocar em cena a memória, o passado, a compenetração recíproca, a teoria da vida retoma em outra dimensão a descriçáo bergsoniana da subjetividade, e o escopo metafísico do estudo dos processos conscientes nela se explicita. A consciência é, com efeito, essencialmente memória que, carregando consigo toda a sua história, invade o presente criando o futuro: “[...] sobre o passado estamos apoiados, sobre o futuro estamos debruçados;

\footnotetext{
${ }^{16}$ Ainda que esse momento da obra náo seja analisado, neste texto, é importante ressaltar que o bloco central que estamos focalizando aqui segue a via aberta no primeiro ato teórico do livro: ele simplesmente aprofundará e ampliará essa compreensão da vida como movimento que não pode ser resolvido em partes ou posiçōes, o qual não pode ser explicado como preenchimento de um plano a priori.
} 
apoiar-se e debruçar-se dessa maneira é próprio de um ser consciente.” (BERGSON, 2011, p. 6). Avançando para o futuro, o passado projeta, invade e transforma; a consciência, por ser memória, é criação. Não é preciso dizer mais que isso para colocar em evidência o âmago desse trajeto teórico: se a vida cria os organismos, por meio de um processo análogo ao dos atos supremos da consciência, os atos livres, a criação dos mundos poderá ser pensada à luz da criação de seres vivos como resultantes de um processo orientado no sentido da indeterminação da matéria. Mais explicitamente, a fertilidade teórica da noção de jorro contínuo dos mundos - os quais iniciam, no exato momento de seu brotamento, um processo de esgotamento - noçáo sobre a qual incide, pela primeira e única vez, em $A$ Evolução Criadora, o termo "Deus"17, depende da demonstração de que a criação tem um fundamento na natureza física, e tal demonstração reside no trabalho pelo qual Bergson expóe a evolução vital como processo que força a matéria no sentido da liberdade, ou seja, no sentido inverso ao determinismo ao qual a materialidade tende. A composiçáo entre indeterminação e criação, baseada na relação entre os seres vivos e os mundos, é o centro nevrálgico da metafísica bergsoniana, o elo que conjuga espiritualismo e filosofia da natureza. Ora, não custa repetir: é a leitura dos dados evolutivos em sua relação complementar que nos oferece o material empírico no qual a intuição se apoia, se ilumina e se materializa em conhecimento, exatamente como expusemos acima, ao explicitar as principais indicaçôes sobre a intuição. Encontramos, assim, a referência a esse papel no interior da cosmologia do terceiro capítulo:

$\mathrm{O}$ alvo da filosofia seria atingido caso essa intuição pudesse manter-se, generalizar-se e, sobretudo, assegurar-se marcos exteriores para náo se extraviar. Para tanto, faz-se necessário um vai e vem entre a natureza e o espírito. (BERGSON, 2007, p. 259).

Se a cosmologia de Bergson obtém êxito, ao conciliar matéria e criação, isto é, determinação e liberdade, de sorte a efetivar o conhecimento absoluto do real, ela o faz na exata medida em que compreende o surgimento dos mundos como jorros sucessivos que imediatamente começam a esgotar-

\footnotetext{
${ }^{17}$ Trata-se precisamente da expressão escolhida para ilustrar o resultado da confrontação entre a duração interior e o conhecimento da natureza física, em que Bergson se refere à similitude provável entre a vida e a matéria como movimentos. Citemos a passagem toda, dada sua importância: "Eu expresso tal similitude quando falo de um centro do qual os mundos brotam... contanto que náo tome esse centro como coisa, mas como continuidade de jorro (jaillissement). Deus, assim definido, nada tem de todo feito, ele é vida incessante, ação, liberdade." (BERGSON, 2007, p. 249).
} 
se, quer dizer, adotam o movimento inverso à criação, dada sua finitude, e caminhariam para a inércia, se não fossem atravessados pelo esforço da vida para atrasá-los e neles inserir, o mínimo possível que seja, criação. $\mathrm{O}$ esgotamento da força ou energia espiritual em matéria, direção inelutável da natureza criada, pode mudar de ritmo e abrir-se a rasgos de criação, através dos movimentos de retomada do sentido próprio ao espiritual que são realizados pelos seres vivos, em sua aventura na natureza. Não é pouco o que uma leitura fiel do movimento evolutivo oferece à cosmologia: se a física já conquistada pelo conhecimento humano tem sua razão de ser num movimento de degradação em homogeneidade, ela deriva de uma heterogeneidade que a metafísica tem de apreender e explorar. O que o método realiza, por meio de seus atos cognitivos, o ser-duração efetiva como movimento real: do movente ao imóvel, do espiritual ao material, trata-se, para a metafísica, de seguir em seus detalhes, de aproximar-se e conformar suas teorias a partir desse processo. E aqui reside precisamente o momento em que o estudo da vida é retomado no seu papel crucial para a cosmologia ${ }^{18}$ esquematizada por Bergson: se a natureza se explica por uma mutabilidade originária, cujo reconhecimento é necessário pelas indicaçóes encontradas, ao se penetrar nas profundezas do mundo físico e encontrar como sua direçáo essencial o esgotamento da mutabilidade nele pressentida, mutabilidade e inversão em imutável - isto é, os processos em que se resolve o real em sua "dupla forma" - podem ser apreendidas e acompanhadas por uma análise de base concreta: "Mas essa conclusão impor-se-á a nós se cercarmos mais de perto a realidade concreta, se não considerarmos mais apenas a matéria em geral, mas, no interior dessa matéria, os corpos vivos." (BERGSON, 2007, p. 266, grifo nosso).

A releitura da evolução das espécies constitui, portanto, um bloco de provas anterior a tal construção cosmológica, do qual tal construção depende em todos os sentidos: as provas serão simplesmente as constataçóes empíricas do movimento evolutivo real e efetivo pelo qual a vida se identifica a algo como uma consciência, uma vez que as tendências nela dominantes se articulam, de maneira a dar continuidade ao movimento de criação. A luta que efetivamente importa não é a que se estabelece entre as espécies em busca

\footnotetext{
${ }^{18}$ A probabilidade de que essa cosmologia tenha fundamento depende da sua resistência a algumas provas: um bloco considerável de tais provas se constitui internamente à construção da teoria, isto é, no próprio movimento de gênese da matéria. Ali, Bergson nos oferece o mais instrutivo percurso de oscilação entre o mergulho em nossa interioridade profunda (e os movimentos nela apreendidos) e a observaçáo dos movimentos do mundo, elaborando, a seu modo, a analogia entre tais movimentos. Trata-se, entáo, de mostrar que as leis da física, que todo o trabalho da ciência sobre a ordem da natureza e sua tendência ao determinismo têm uma razão de ser metafísica, e esse é o centro do livro.
} 
de sobrevivência, mas aquela que contrapôe a vida à matéria e cuja maior vitória será a espécie humana.

O exame dos fatos é, assim, mais do que o filtro da intuição: enquanto base concreta para a tese do elã criador, ao refratar a nebulosa em dados observados e iluminadores, ele possibilita que se realize uma teoria da vida estrito senso. Ela é filosófica, e não propriamente científica, mas exatamente por isso depende da ciência, do trabalho sobre os dados que devem ser lidos em seu sentido essencial. No entanto, qual é a diferença entre as duas leituras de dados, entre os dois trabalhos com os fatos? Precisamente a que separa uma adequação dos dados às categorias intelectuais da compreensão desses dados como conjuntos no tempo ou como marcas visíveis do curso do tempo. O que dizem os fatos evolutivos, se compreendidos em sua interdependência, como totalidades ou linhas mestras que convergem para um sentido? Dizem algo simples: a evolução das espécies submete-se a inúmeras contingências, seus resultados dependerão em larga medida das relaçóes entre os organismos que ela deposita e o meio em que eles tentarão subsistir, conservar-se; mas, eis o essencial, ela é um movimento dotado de intenção, e a conjugação entre suas tendências dominantes permite apreender essa intenção como $a$ busca incessante de indeterminação, liberdade, criação. Trata-se, desse modo, de retomar os fatos em seu sentido "bruto" e neles encontrar as balizas para a fundamentação, a ampliação e o aprofundamento da hipótese em curso. A teoria do elã vital, agora figurada em ideia geral da evolução, é uma das fontes de sugestão que faculta ao filósofo avançar: assim se configura a hipótese da evolução das espécies como movimento com direção, dotado de intenção, a referida corrente invisível que busca inserir indeterminação na matéria. Essa descrição da vida encontra, nos dados da biologia evolutiva, sua confirmação e, mais que isso, sua explicitação? Ao conformar os resultados da evolução, organismos e espécies distribuídos pela natureza (e seguindo seus próprios itinerários, que compreendem, por vezes, recuos, fracassos, posiçóes ambíguas em suas conformaçóes, entre outros problemas para a ciência), essa hipótese alarga seu escopo e recebe, ela mesma, novas determinaçóes? As respostas claramente positivas a essas duas questóes constituem o ponto alto da articulação entre biologia e metafísica a que estamos nos reportando. Essa força reside precisamente na consistente explicitação de que as diferentes espécies, as quais se relacionam de forma antagonista e complementar, são o resultado concreto das tendências divergentes contidas na Vida como todo de implicação recíproca. As análises ali desenvolvidas trazem esclarecimentos e, sobretudo, desdobramentos da leitura do movimento evolutivo como 
processo dissociativo, movimento que tem na materialidade o agente da dissociação, portanto, a sua ocasiáo de efetivar-se, porém, cuja causa profunda permanece sendo uma força própria a um conjunto de tendências, isto é, um todo instável.

A análise empreendida por Bergson sobre os dados e as classificaçóes dos biólogos é a tentativa de delimitar a direção da vida, quer dizer, de um movimento que não evolui em linha reta. Os organismos e espécies são comparados pelo filósofo a estilhaços de seguidas explosôes, compondo uma série de redes entrelaçadas. Eles resultam do esforço do elã vital para inserir-se na matéria, e os primeiros organismos devem ser entendidos (ainda em nível suposição) como massas protoplasmáticas simples, dotadas, entretanto, de uma mínima plasticidade e, segundo a sugestão da tese do elā vital, comportando, em sua extrema simplicidade, "[...] a formidável impulsão que devia lhes alçar até as formas superiores da vida." (BERGSON, 2007 , p. 100). O crescimento desses organismos iniciais logo encontrou seus limites, e a divisăo passou a constituir, junto com o esforço para manter sua composição propriamente vital, isto é, de resistir à morte, o seu comportamento. Individuação e reprodução marcam inevitavelmente os seres assim originados. Percebe-se, desse modo, que Bergson segue apenas, nessa releitura, os pontos de partida sugeridos pelo trabalho de elaboraçáo da tese figurada pelo elã vital. O raciocínio mais limpo possível que se delineia a partir das sugestóes do elã indica elementos nos quais o filósofo deve concentrar sua atenção e os sinais que devem guiá-lo, para, partindo dos organismos e espécies, remontar ao movimento que os originou. Entre esses elementos, está a causa profunda da divisão dos organismos originais, a saber, a instabilidade própria à vida, enquanto conjunto de tendências: é "[...] próprio de uma tendência desenvolver-se em forma de feixe criando, somente pelo fato de seu crescimento, direçôes divergentes entre as quais se repartirá seu ela." (BERGSON, 2007, p. 100). A tarefa, por conseguinte, se delimita: trata-se de partir dos organismos e espécies e, explorando as suas características, extrair de suas linhagens as direções que eles representam, ou seja, sua função e suas relaçôes dominantes no quadro evolutivo. Além de só considerar esse conjunto de sugestôes, a análise de Bergson manterá em seu horizonte estar tratando de progressos e não de coisas.

As diferenciações que se sucedem nesse esforço buscarão enumerar as principais características da primeira divisão sobre a qual os biólogos estão, em geral, de acordo: vegetais e animais, tomados como grupos que 
acentuam características, exibem seu modo de alimentação, sua relação com o movimento e a intensidade de consciência ou sensibilidade com a qual são marcados como sinais do papel que desempenham para o avanço desse movimento originário ou impulso formidável, o progresso do elá. Eis o ponto fundamental do encontro entre a intuição do filósofo e a análise dos cientistas: trata-se de notar e enfatizar a articulaçáo concreta entre as tendências que essas características indicam, sugerem, apontam. A importância da capacidade do vegetal em armazenar energia será o complemento preciso da potencialidade de movimentos progressivamente mais indeterminados que a animalidade carregará consigo. A planta armazena um excedente de energia, produzindo mais do que necessita para manter-se em vida, e o fato de não se movimentar é indispensável para tal; marcada pela imobilidade, sua inconsciência, advinda necessariamente das propriedades que lhe permitem desenvolver a função clorofílica, se torna uma aliada e não um problema. Do outro lado, o animal se move para buscar seu alimento, e a condição para que ele se mova adequadamente é sua capacidade de receber e processar estímulos exteriores em grande quantidade. Além de avançar na ênfase sobre os modos de alimentação e modos de ação das duas tendências, Bergson não foge ao risco de aprofundar essa diferenciação, buscando, sob esses "signos superficiais" que são a fixidez e a mobilidade, as "tendências mais profundas" (BERGSON, 2007, p. 111). A intensificação da consciência nos animais, exata contrapartida de seu adormecimento nos vegetais, surge como um critério para discernir o que é importante em cada uma das duas linhagens, importância derivada, por sua vez, da relação com as sugestôes iniciais da teoria do elá vital. A interpretaçáo dos fatos conforme sugestóes recebidas confere sustentação à interpretação de que o elã de vida se insinua na matéria, para dela obter condiçóes de progredir em direção à liberdade crescente. É assim que o percurso busca "[...] determinar em termos precisos o que une e o que separa os dois reinos" (BERGSON, 2007, p. 115), retornando, sempre que necessário, à suposição que o trabalho desenvolvido na construção da tese do elă vital possibilitou "entrever", a do esforço incessante da vida em prol da liberdade. Os vegetais desempenham o papel primordial, na medida em que são reservatórios de energia: sem cumprirem tal função, não haveria nenhuma condição de movimentos livres na natureza. Mobilizando as consequências da teoria da duração, da teoria da memória, como figura aprofundada da consciência, e a teoria do elá vital, desenvolvida no capítulo inicial, o trabalho de oferecer uma interpretação filosófica da evolução vital como teoria intuitiva explicita a conjunção entre o recurso à materialidade 
dos fatos e a apreensão de si como criação de si, dada na intuiçẫo. Os dois reinos inicialmente examinados mostram sua unidade originária na memória que carregam em si das potencialidades dissociadas e apresentam-se como conjuntos de organismos que expressam o esforço vital no que tem de essencial. Bergson não poderia ser mais claro, ao sintetizar como os vegetais realizam a façanha de obter uma suspensão temporária do gasto de energia solar que, sem eles, é incessante:

Tudo se passará como se o esforço visasse simplesmente utilizar da melhor maneira uma energia preexistente, que ele encontra à sua disposição. Ele só tem um meio de obter sucesso: obter da matéria uma tal acumulação de energia potencial que ele possa, num momento dado, ao disparar um gatilho, obter o trabalho necessário para agir. (BERGSON, 2007, p. 116).

É importante ainda sublinhar como o filósofo pode passar da primeira divisão, entre vegetais e animais, para o domínio da animalidade, bem como encontrar, no seio da animalidade, sua dissociação interna. Qual é o ponto preciso que lhe permite especular, no sentido bem especial que esse termo recebe em sua filosofia? É, se podemos assim nos expressar, a própria economia de sua reflexão: seguindo apenas a tese do elã, ou seja, movimento para a indeterminação, ele se arrisca a retomar o domínio dos dados da biologia e retirar as liçôes mais diretas desses fatos, uma vez que eles estão libertos das categorias físico-químicas que lhes foram atribuídas, de maneira exterior. $\mathrm{O}$ curso dos fatos respeitado em sua imanência é apenas remetido a essa descrição da vida, único critério aplicado para perceber, num conjunto de dados, o seu significado concreto.

O simples "lance de olhos no conjunto do mundo organizado" (BERGSON, 2007, p. 137), isto é, um exame ou uma visada que não isola os organismos, não busca examinar aquela espécie em seu trabalho de adaptação, aquele organismo em seu desenvolvimento do nascimento à morte; pelo contrário, tenta delinear as relaçóes entre organismos e espécies, indicando na animalidade a maneira pela qual ela cumpre sua direção essencial, a execução de movimentos livres pela explosão da energia que lhe é fornecida pelos vegetais. $\mathrm{O}$ olhar do filósofo considera o processo evolutivo e o conjunto de relaçóes entre seus agentes: o processo exibe o desenvolvimento da capacidade de execução de movimentos não necessários vinculado à modificação na forma do corpo dos organismos animais e à sua complexa estruturaçáo concentrada em torno do sistema sensório-motor. Os fatos reelaborados à luz 
da nova definição da vida apontam com mais segurança essa "posição" que os mecanismos sensórios e motores ocupam "face ao resto do organismo". As formas vitais, cuja parte de contingência em sua criação Bergson deixa intacta (não há predeterminação das formas, e a adaptação ao meio continua sendo o crivo para que algumas sobrevivam e outras sucumbam), servem de veículo a uma atividade cada vez mais livre, e o sentido evoluído das espécies ditas superiores ganha, então, um grau de clareza e concretude antes impregnado de referências à racionalidade humana, uma vez que se trata precisamente dessa capacidade de movimentação. A evolução caminha no sentido da indeterminação progressiva das respostas aos estímulos ao meio, ao mundo. $\mathrm{E}$ essa indeterminação progressiva dos movimentos, base concreta da liberdade, está diretamente ligada ao desenvolvimento de um sistema nervoso altamente complexo e qualificado. Uma das principais conclusóes da obra anterior, Matéria e Memória, a qual envolve a tese de que a consciência náo se reduz ao desenvolvimento de um cérebro altamente complexo, porém, depende dele, em larga medida, retorna ao campo da investigação, agora enquadrada por outro conjunto de fatos e plena de novas consequências, não mais referidas à união entre matéria e memória em nós, mas entre vida e matéria no Todo:

Um sistema nervoso, com neurônios colocados um na ponta do outro de tal modo que na extremidade de cada um deles se abrem vias múltiplas, em cada uma das quais se pôe uma questão diferente, é um verdadeiro reservatório de indeterminação. Que o essencial do ímpeto vital tenha sido gasto na criaçáo de aparelhos desse tipo é o que nos parece mostrar um simples lance de olhos no mundo organizado. (BERGSON, 2007, p. 127).

A linha da animalidade se desdobrará conforme novas tendências que se explicitaráo, sempre com essa marca, a do movimento. $\mathrm{E}$ as respostas às questôes colocadas aos organismos animais pelo meio serão construídas e realizadas de modos diversos, a partir da dissociaçấo. Para deslindar as novas tendências, Bergson dispóe, assim, de um critério: quais prerrogativas conferem às distintas linhagens da animalidade seu poder de resposta indeterminada? Sob a presidência desse critério, ele integra à análise dois novos conjuntos de fatos, os quais resumimos aqui: a evidente contraposição, em toda a história evolutiva, entre o ímpeto do elã que quer avançar, e a necessidade das espécies de sobreviver, e, portanto, de se conservarem exatamente como são; tal contraste ganha contornos agudos com a proliferação de espécies semelhantes, que passam a competir a até a se entredevorarem. O segundo conjunto de fatos, derivado do primeiro, é a evidência oferecida pelo estudo da fauna 
primária: o perigo que o movimento evolutivo sofreu com o surgimento da um "envoltório mais ou menos duro" (BERGSON, 2007, p.141), que aprisionava o animal e atrapalhava ou mesmo paralisava seus movimentos. A história evolutiva nos mostra, pois, que o desenrolar da vida produziu efeitos que poderiam ter destruído a possibilidade de que ela continuasse o seu caminho. No seguimento dessas consideraçóes, Bergson examina os principais grupos animais e diferencia os dois pares ligados ao sucesso e ao fracasso. Procura, então, o sistema nervoso das duas espécies que venceram para examinar sua maneira própria de organização. É assim que ele chega às "duas potências imanentes à vida", instinto e inteligência, e todo o resto de sua interpretação da biologia se concentrará sobre essas duas novas tendências que, acrescidas do torpor vegetal, constituem as direçóes essenciais da evolução vital.

A título de conclusão, queremos apenas indicar algumas consequências exploradas pela cosmologia que se segue no livro. A releitura dos fatos biológicos, refração da nebulosidade intuitiva pelos fatos organizados em ciência, evidencia que a atividade vital é uma composição com a matéria, para atravessá-la e levar adiante o impulso criador. Ora, essa atividade pressupóe a exigência de retardar o movimento próprio à materialidade, desacelerar a tendência à inércia e, assim, confrontar-se com ela. Para fazer-se, a vida tem, então, que cindir suas tendências em organismos complementares, em dois tipos de açôes imputadas aos organismos: conservação de energia para gastá-la explosivamente, única maneira de fazer com que os movimentos resultantes desse emprego da energia sejam variáveis e imprevistos. Os organismos, em sua história, progressáo no tempo que se submete às imposiçóes adaptativas e se distribui no espaço segundo o viés que a luta pela sobrevivência determina, expressam a ação de uma vontade e sua busca de eficácia. Animais complexos e muito evoluídos apresentam, desse modo, a aparelhagem necessária para que seus atos voluntários sejam extremamente precisos, eficazes e independentes: um sistema nervoso altamente organizado. Os vegetais, por sua vez, são capazes de um armazenamento de energia que, utilizada pelos organismos dotados de sistema sensório-motor extremamente sofisticado, proporcionalhes a capacidade de movimentar-se com liberdade. Os significados da animalidade e da vegetalidade cruzados permitem concluir sobre o sentido da vida como um todo: a atividade biológica visa a juntar energia e liberála em movimentos livres. A vida inteira, o que inclui animais e vegetais, se mostra um "[...] esforço para acumular energia e para liberá-la em seguida em canais flexíveis, deformáveis, em cujas extremidades ela realizará trabalhos infinitamente variados." (BERGSON, 2007, p. 254). 
$\mathrm{Na}$ continuidade desse trajeto, Bergson afasta progressivamente os obstáculos e as obscuridades em torno da ideia de criação. Enfatiza que não há "coisas", apenas "açôes", e que o mundo esgota progressivamente a sua mutabilidade. Há movimentos de sentido inverso, isso é tudo, e nisso se resumem a matéria e vida. A energia, conceito no qual estâo implicadas as noções de movimento e de ação, não pode ser pensada como ligada a suportes ou partículas extensas - assim, fazer e desfazer são as formulaçóes adequadas para pensar a gênese da matéria. A açáo, ao contrário da coisa, pode ser pensada como criação, progresso, "avolumação". A vida e a materialidade são movimentos inversos um ao outro, mas, como movimentos, são, ambas, fluxos indivisos. Nas páginas finais do terceiro capítulo de $A$ Evolução Criadora, o filósofo trata de elaborar a significação última da vida, a partir da gênese realizada, retomando a descrição da atividade vital que foi exposta no segundo capítulo do livro, agora à luz das novas aquisiçóes. O elã vital, desde o início tomado como imagem que melhor expressa o movimento evolutivo, recebe da análise dos fatos uma delimitação mais precisa, através de seu significado essencial - exigência de criação.

PINTO, Débora Morato. Objective analysis and subjective apprehension in Bergsonian metaphysics: the intuition of life and the sieve of facts. Trans/form/ação, Marília, v. 40, n. 2, p. 9-46, Abr./Jun., 2017.

ABSTRACT: This paper intends to explain how the philosophical method developed and applied by Bergson - intuition - articulates different levels of our experience. To this end, we will try to extract some lessons from a special moment in the application of this method, in which the dive into psychological interiority is related to the objective vision of exteriority. Our analysis will focus on the central part of Creative Evolution, the metaphysical nucleus of Bergsonian philosophy, in which we find a reinterpretation of the evolutionary biology of the 19th century. This reinterpretation has as a consequence the most important of Bergson's cosmological theses. More precisely, though the cosmology developed in this book can be regarded as the most paradigmatic performance of intuition, our attention will be directed to an earlier methodological step, the philosophical interpretation of the data of evolutionary biology that underlies the essential statement that consciousness is coextensive with life.

KEYworDs: Duration. Life. Biology. Cosmology. Intuition. Experience.

\section{REFERÊNCIAS}

BERGSON, H. Essai sur les données immédiates de la conscience. Paris: PUF, Quadrige, 1993. 
. Duração e simultaneidade. São Paulo: Martins Fontes, 2006.

. L'Évolution créatrice. Paris: PUF, 2007 (Éd. Critique Le Choc Bergson).

. Matiére et mémoire. Paris: PUF, 2008 (Éd. Critique Le Choc Bergson).

. La Pensée et le mouvant. Paris: PUF, 2009 (Éd. Critique Le Choc Bergson).

. La consciente et la vie. Paris: PUF, 2011 (Éd. Critique Le Choc Bergson).

BERNET, R. La consciente et la vie comme force e et pulsion. In: RIQUIER, C. Bergson. Paris: Les Édtions du Cerf, 2012. p. 25-54. (Les Cahiers d'Histoire de la Philosophie).

DELEUZE, G. Bergsonismo. São Paulo: Editora 34, 1999.

FRANÇOIS, A. Bergson. Paris: Ellipses, 2008 (Coll. Philophilosophes).

LAPOUJADE, D. Puissances du temps : versions de Bergson. Paris: Les Éditions de Minuit, 2010.

PINTO, D. C. M. Notas sobre a noção de elã vital: consciência e totalização na teoria da vida. In: CARNEIRO, M. C.; GENTIL, H. S. (Org.). Filosofia francesa contemporânea. São Paulo: Cultura Acadêmica, 2009. V. 1. p. 381-396.

PRIGOGINE, I. Entre o tempo e a eternidade. São Paulo: Companhia das Letras, 1992.

PRIGOGINE, I.; STENGERS, I. A nova aliança: a metamorfose da ciência. Brasília: Editora Universidade de Brasília, 1997).

RIQUIER, C. Archéologie de Bergson: temps et métaphysique. Paris: PUF, Epimethée, 2009.

. Les directions divergentes de l'evolution de le vie : torpeur, intelligence, instinct. In: FRANÇOIS, A. (Éd.). L'Évolution créatrice de Bergson. Paris: Vrin, 2010. p.125-166. (Coll. Études e Commentaires).

WORMS, F. Bergson ou les deux sens de la vie. Paris: PUF, Quadrige, 2004.

Recebido em 07/01/2017

Aceito em 16/02/2017 
PINTO, D. M. 